Meta

Journal des tradlucteurs

Translators' Journal

\title{
Translation and le différend
}

\section{Marilyn Gaddis Rose}

Volume 35, numéro 1, mars 1990

Actes du colloque international " La traduction proligère "

URI : https://id.erudit.org/iderudit/002781ar

DOI : https://doi.org/10.7202/002781ar

Aller au sommaire du numéro

Éditeur(s)

Les Presses de l'Université de Montréal

ISSN

0026-0452 (imprimé)

1492-1421 (numérique)

Découvrir la revue

Citer cet article

Gaddis Rose, M. (1990). Translation and le différend. Meta, 35(1), 126-132.

https://doi.org/10.7202/002781ar d'utilisation que vous pouvez consulter en ligne.

https://apropos.erudit.org/fr/usagers/politique-dutilisation/ 


\section{TRANSLATION AND LE DIFFÉREND}

MARILYN GADDIS ROSE

State University of New York, New York, USA

Lightfingering was the way Wolfram Wilss put it. In his communication at the International Comparative Literature Association congress in August 1982, Professor Wilss observed that in translation studies, especially as we move into concepts and conceptualizing, seeing where or whether our discipline can accommodate theory, we tend to "lightfinger." I would go further: like Fagin in Oliver, we gleefully "pick a pocket or two." I knew as I listened to Professor Wilss that Manhattan morning that I myself along with many other participants in that session - was in fact being fingered. And I, no more than the others, I suspect, have mended my ways. And probably won't. Indeed, it is the nature of our quest, i.e., to learn more about translation, we investigate everything interesting about language and communication that comes our way. Whether or not we in Translation Studies start trends in literary theory and criticism, we certainly give such trends momentum. I would claim, for example, that Jacques Derrida not only owes his translators the usual authorial debt, a concept he takes up in Des Tours de Babel (1980/1985), but that it is his translators' ruminations on their task which has reflected back on the meaningful knots imbedded in the knots of his text and, I surmise, led him further into the distinctive recesses of natural languages. (I am thinking of Geschlecht II and John P. Leavey, Jr.'s translation of it.) "Lightfingering," I would suggest, can be profitable both for the pocket-picker and the pocket-picked.

Currently for me there has been profitable looting in le différend as developed by Jean-François Lyotard. When it was confirmed in late 1987 that Lyotard would be giving a seminar in my department in spring 1989, I decided to give myself a self-help course in Lyotard's ruvre. In Le Différend (1983) I came across one of the best articulated descriptions of the sensation of translation I have still ever encountered. Proposition 22 as translated by George Van den Abbeele calls:

(...) le différend the unstable state and instant of language wherein something which must be able to be put in phrases cannot yet be. This state includes silence, which is a negative phrase, but it also calls upon phrases which are in principle possible. This state is signaled by what one ordinarily calls a feeling: One cannot find the words, etc. A lot of searching must be done to find new rules for forming and linking phrases that are able to express the différend disclosed by the feeling.

There is undeniable frustration and difficulty. Proposition 22 warns us that we must find new rules to express the différend disclosed by the feeling "unless one wants this différend to be smothered right away in a litigation and the alarm sounded by the feeling to have been useless" (p. 13). Does not this definition of the différend sound like a description of the negative aspects of translating? Or, more exactly, do we not inhabit the différend when we translate? However, the experience of the differend, like that of translating, has its positive aspects. Proposition 23 assures us that symmetry can occur; i.e., besides the pain of not being about to use language as we expect to is the pleasure of being able 
to invent a new idiom. Haven't translators always recognized that "what remains to be phrased exceeds what they can presently phrase, and that they must be allowed to institute idioms which do not yet exist?"

Although Lyotard's Propositions 76-80, which deal specifically with translation, while undisputable, are a little simplistic, as we shall see, I felt confident - as did my translation theory students this past March - that when April and Lyotard came, he would be gratified that we had discovered the applicability of the differend to translation. Gratification is besides the point. Albeit gallantly given to kissing hands, he was not even interested. What he says about translation in Au juste (1979) is what he says repeatedly. Wlad Godzich in Just Gaming (1985: 53) puts it this way: It so happens that languages are translatable, otherwise, they are not languages. It is as if translatability and untranslatability belonged almost solely to reference, including contextual reference, and not to the languages per se. But I am not going to let Lyotard's apparent indifference discourage me. What matters is that here is a philosopher of language who does not argue himself into the impossibility of translation. (Nine of the 12 texts glossed in Le differrend are translations; propositions 76-80 are followed by readings of Kant's Transcendental Ethics and Gertrude Stein's How to Write.) In the meantime I am conducting a survey of translator-colleagues on their experience of the différend in translating and receiving thoughtful responses. I hope to have the results available for Volume VI of the ATA Series. (I hope II may prevail upon some of you here to take part and have brought a few copies with me for you.) What I should like to do today is explore with you how or whether Lyotard's version of Postmodernism accommodates malgré lui the translation process.

After all, we appear to be in a period of consolidation in Translation Studies, as we the players discover we have been using the same rules, if not the same scoring systems. It will surely be instructive to check whether, as usual, our current consensus reflects malgré nous the consensus in the humanistic disciplines as a whole.

To give our exploration textual data, I shall take a few examples from my current project, Sainte-Beuve's Volupté (1834). The nature of the plot is a fictionalized encapsulation of the Lyotard language games in which the différend emerged for him and is experienced by us, or any Gadamerian partners in language communication. Further, the characters playing these language games are particularly aware of the chasms between one game and the next, one player and the next or, in Lyotard terms, are aware of the différend in their communication. Volupté itself embodies as it mirrors the translator's experience of it.

Volupté is an extraordinary complex network of language games. Further, since I am translating it, I am engaged in another language game. My translation, unless another comes out in the interim, will be the first ever in English, and hence in baldest terms an original translation. What the originary text, the pre-text, of Volupté was is now the best known thing about it: a roman à clefs about his affair with Adèle Hugo. A roman à clefs, after all, is one of the most exclusive literary language games. I am confronting the issue of origin, for I would say that now, over 150 years later, the roman à clefs is the least interesting aspect of Volupté and in itself would never have moved me to translate the novel. Volupté, which 1 have tentatively subtitled The Sensual Man, intrigues me because it is an inside view of an introspective, sensitive, intellectual who is trying simultaneously to castigate and rationalize his abuse of women. As for the originary pre-text, there is no evidence that he abused Adèle Hugo - apart from telling his world about it.

Further - but beyond the scope of this discussion, although by no means beyond the compass of either translating Volupté or situating it in a period-norm régime (i.e., R.omanticism) - is its self-reflective style which expands Romantic rhetoric to the brink of disruption. 
For the discussion here I want to limit my use of Volupté to the courtship games which comprise its chief web of plots. These games will let us explore that form of Postmodern translation theory that can be extrapolated from Lyotard, and suggest that language games epitomize translation and réciproquement. Although Lyotard himself as we noted believes translatability is a characteristic of language, he curiously imagines that language games are untranslatable. I shall simply brush this proviso aside. If language games are comprised by language — otherwise they would be some other kind of game - they can only embody translatability or its possibility.

Since Volupté is likely not to be read even by doctoral students preparing for their comprehensives (a situation I hope my translation can somewhat alter), let me state that it is a historical novel about the consular period of Napoleon. Sainte-Beuve's fantasized projection Amaury, the first-person narrator, is an intimate of a highly suspect counterrevolutionary, the Marquis de Couaën. However, very early in the narrative the marquis is put into protective custody, and Amaury, devoted to the marquis and bewitched by the obliviously exploitative marquise, follows them to sites which make prisoner visitation convenient. Thus, a narrative that might have initially seemed to promise action and suspense becomes a tale told from the sidelines and a rhetorical ploy. In the 1820 s, Amaury, now an ecclesiastical administrator in his early sixties, returning to his post in New York, transcribes a record of his misused sensuality for a younger friend whom he sees making the same kind of mistakes. This is certainly the first language game: the rules and hence rhetoric require repentance, but writing this confession allows Amaury to flagellate and delectate his senses simultaneously. Every relationship within the novel rests on a language game also. Amaury the sensualist is besotted over prostitutes, but that part of his life is off-stage; we do not know what idiom he uses in those circumstances. With Mlle Amélie de Liniers, a charming young neighbor who would have made a loyal wife in the cordial arrangements of his social milieu, he prescribes the affective level of interchange, and she, a perceptive, open young woman, cannot transgress the rules of this regime, which I would characterize as guarded camaraderie. He, in turn, acquiesces to the regime prescribed by the Marquise de Couaën who maintains their relationship at a level of verbally unacknowledged intimacy but tremulous and quivering restraint. But the cynosure of gamesmanship in Volupté is Amaury's relationship with Madame de R..., whose spouse for reasons never divulged is not living with her. Amaury and Madame de R... keep each other playing out this "predilection" by a "thousand tricks and ruses which cut, badgered, and harrassed." Although he is this sympathetic socialite's standard escort and rarely leaves her current domicile before eleven, the regime requires that he keep watch beneath her bedroom balcony at midnight. The regime is quite regimented: he watches the movement of lights from room to room as they come to consolidate in her apartment, she pulls up a corner of the curtain to make sure he is really there, she practices on the harp "as a prelude to the rising of the Evening Star." Then there is a pause while he visualizes her hair being let down by the chambermaid. And "then," he reports, "she would lean over her little balcony a moment to throw me some sign of adieu - a wave of the hand, a scribbled note, the corsage at her bosom." Now at the telling at least, he sees the game as romantic juvenilia: "I never missed that rendezvous and watched beneath that casement like a stubborn sentinel, rain, snow, every phase of the moon, stock-still or prowling, a suspect creature for the rare passers-by who prudently moved away from my shadow." If Madame de R... takes liberties with the rules, practices on the harp too long, for example, Amaury is moved to outrage and the game of rape fantasy: scaling to the wall and perpetrating acts of irreversible violence (pp. 237-238).

They stay in the relationship because they have developed both the rules of their game and the pragmatically proven ways of breaking the rules which, not especially 
paradoxically, are the only ways of ensuring the continuance of the game. Mentally they make themselves delay in the anxiety-producing space of the différend. Remember Lyotard's description in Proposition 22 calls this "the unstable state and instant of language wherein something which must be able to be put in phrases cannot yet be. A lot of searching must be done to find new rules for forming and linking phrases that are able to express the differend disclosed by the feeling." Then since the two of them do not, really could not, love each other, they must draw back from the new rules their courtship games are always almost automatically triggering. I.e., they find the new rules, but they do not have the new feelings. They pay the penalty of frustrated expression. To return to Proposition 22, they must find new rules to express the differend disclosed by the feeling "unless one wants this différend to be smothered right away in a ligitation and the alarm sounded by the feeling to have been useless."

To move from the specifics of translating Volupté, a complex of language games within the language game of fictional narrative, to translating literature generally, we have always known, to extrapolate from La Condition postmoderne (p. 23), that as translators we make moves in and between language games. When we say that translators must be in control of the target language, comfortable in the source language, sensitive to norms and traditions of both literatures, aware of the conventions of transfer, we are establishing the rules for entering and/or leaving the game. We are also recognizing that the rules must be observed - or broken - with care because of the desired end result to the match. In translation the game is not won, although it can be lost. What is important is to play. Put another way, the important thing is to establish and/or maintain the social bond (lien social). We could say that as language games go, translation might be a kind of relay. The transmittal is the différend; the text is the baton fabricated from the language by the source-language author and taken from him or her by the translator who may handle it differently, even reshape, reconstitute, or reverse it, before handing it on to the readers some of whom may form or formulate slightly different batons which will be taken by more translators and passed on to more readers. Whatever the first bâton's relationship to the mental image or affective experience about a hypothetical, platonic stick of wood, there needs to be a basic, valid trust in the mutual resemblance of the batons being taken from the author and handed to the reader by the translator.

Propositions 76-80 deal specifically and evenhandedly with translation. Propositions 78 and 79 contain sub-propositions which we can profitably review.

1) Phrases governed by different rule systems (régimes) are untranslatable. Somewhat true in the sense of total communication between partners. False in the sense of translation in the narrow sense, as is the case here.

2) We cannot arbitrarily select out the sense effected by syntax from that effected by lexicon. True.

3) Translation presupposes that the sense of the phrase in the source language can be reconstituted in a phrase of the target language. (Lyotard uses langue de départ and langue d'arrivée.) True.

4) Sense determined by syntactic form depends both on the regime of phrases governing the phrase in question and the type of discourse in which it is found. True.

5) This regime and this genre (i.e., of the discourse) determine the governing ensemble of rules of phrase formation, linking, and validation. True.

6) Thus a translation presupposes that a regime and genre in one language will have their analogue in another or at least that the difference between the two regimes and/or genres in one language has its analogue in another. Difference here means intra-language relationships and adjustments and accommodations. Lyotard's example, you will recall, is putting French narrative present and past into Chinese. True. 
7) The translator may have to have recourse to the transversal appurtenances and logical pertinencies between languages. (Pertinences will cover both ideas in French.) True.

Yet there are important provisos.

8) In terms of sense alone, it may be possible to transcribe. You must leave (Vous devez sortir) may transcribe the sense of Leave (Sortez), but that is not translating. Indeed it is not! If asked to translate Vous devez sortir into English, I would probably say, Please leave, implying a firm tone of voice. For Sortez, my first response would be Get out or You can't stay here. (His translator George Van Den Abbeele uses Come out and You must come out.) When Lyotard states that Vous devez sortir and Sortez are not even intralingual translations, we infer in our own différend of text engagement that Lyotard wrestles with the interpretative side of translation and thus can give us moral support for the anxieties and gratifications implicit in our task. (In classroom interchange he is in fact extremely supportive and would have translators accept discrepancies as inevitable givens.)

9) Translation is not a body of abstract concepts; it is a reconstitution of analogous worlds: These universes are constituted by the way the instances (not only the sense but the referent, the addressor, and the addressee) are situated as well as by their interrelations (p. 49). I believe Lyotard's proposition both contains translation and allows for expansion. This proposition, I suggest, is fully amplified in Jan de Waard and Eugene Nida's introduction to From One Language to Another (1986): "For any communication there are eight principal elements: source, message, receptors, setting, code, sense channel, instrument channel, and noise" (p. 11).

Let me now, circular as the process may be, apply these nine sub-propositions to my own project. I think I find as a result that my own task, my own dithering in the différend, i.e., translating Volupté, is made more orderly. I am more aware of where and what my mental space is when I am translating. Let me pass Volupté in review. The etymological lexicon and syntax which make it quite distinctive, even for Romantic writing, should make it a very clear example.

1) The regimes of literary fiction of French and English are similar. The passage of over 150 years means that fictional rhetorics have changed somewhat. Bulwer-Lytton might have been the most appropriate contemporary translator, so Sainte-Beuve may have to be toned down somewhat to preserve the social bond.

2) Yet, when we interact with the sentences of this novel with its intricate Latinate syntax and pre-Freudian lexicon, we are confronted with difficult choices of mood and manner at all times. We do not want to overly simplify the sentence structure or insert lexical anachronisms.

3), 4), 5) 6) Felicitously, French and English have had continuously close literary relations. It is my impression that first-person narratives have been more continuously in favor in French literature than in English-language literatures. Still, it is an extremely common form for English readers who bring to such a novel a set of accommodations. Further, a literary translation is overt, in the sense used by Juliane House. We may agree in some way that the translation reads as if the author wrote in the translator's language, but we bring a set of accommodations to reading a translation. It would be a mistake, however, to overly modernize the style of this novel, widely read in its own times, largely unread after Sainte-Beuve's death in 1869 , for it is uncannily Postmodernist in its neobaroque reflexiveness. The style is integral to its conflicted, complacent self-condemnation.

7) With Volupté I would be surprised if I need to have recourse to transversal pertinencies. I will be obliged, however, to add pertinencies, i.e., use footnotes for the historical references which present-day readers need even in French.

8) \& 9) With a novel so very dependent upon language games for first of all, its existence as a roman à clefs and second for its fable, characterization, and disruptive 
texture, with the differend veritably a one-word summation of its characters' inner life transcription may be unthinkable. What is needed is a reconstitution of an analogous world so that readers of Volupté in 1990 can see in Amaury a not unlikable victimizer and victim. That readers will recognize the persistence of verbal sexual power plays and psychological abuse. These moves of language games between the sexes have moved into our own presumably much more enlightened era probably without a break even though legal conditions and customs have improved women's lot. His confession should sound neither vaguely archaic, as would happen if I tried to make English words follow a French regime, or disturbingly anachronistic if I moved too close to contemporary idiom. Sainte-Beuve's pre-text, the originary text, soon ceased to be his pretext and he became perhaps sincere in spite of himself when he lost himself in Amaury's ambivalent selfcastigation.

If, as I maintain, translation metatheory must have categories for speculation and methodology, with the latter requiring description, evaluation, verification for equivalence, and bias accommodation for the purpose of illuminating process and practice, Lyotard's Postmodernist remarks would seem promising. What, by my own checklist, his propositions cover only implicitly is bias accommodation. Such bias is the translator's own; mine in this case. Accommodation is one of the moves I must make in the différend of my translating. I.e., even though I cannot keep from empathizing with Amaury's game opponents, his female victims, I must keep my antipathy towards him in check.

To test out my tentative conclusion about translation and language game, we would need, of course, more testing, at least more juxtaposing with a variety of texts. That is why I began in July what will probably be a two-year study of translator's experience with the différend. What we need with any translation theory are actual texts, not manufactured examples. The differend is a space, a mid-region, a between - or a quality of betweenness - and would appear to emphasize the translator and the translation process in the speculation category. When the differences between the source and target expectations are slight or when the conventions are well-established and adequate, translation is relatively easy and our passage through the differend is brief. When the differences are considerable, when we must construct the expediencies (or pertinences) ourselves, then we may remain in the space of the différend a long time - or bail out in panic, pitching the baton. The resulting methodology in a translation theory derived from Postmodernism which doctrinarily eschews theory would appear to emphasize sensitivity to cultural setting, rhetorical norms. The relativism in Postmodernism would certainly keep the translation theory researcher on the alert for personal bias and ideological pressures. Familiarity with Postmodernist attitudes would surely encourage an energetic response to a total text, both expressed and unexpressed. Such text engagement might even let us speculate why we find some translations good, some bad; some ageless, some dated. It is too early to say that Postmodernism will generate the next set of rules, a regime, as we have used the term, in translation theory. Further, most translators I know find post-structuralism or deconstructionism too peripheral, hermeneutics too restrictive, formal logic too reductive. Many of us, I believe, have looked askance at Postmodernism, fascinating, yes, but not clarifying. Clarifying is what I think Lyotard's concept of the différend and language games is. It can occupy a hitherto unoccupied space. We really want a theory that gives us a positive return on our task. What I can report now is that when I put Lyotard's modest propositions to the test, I was impressed. Like Amaury, "my head was full of enterprising projects." Or, like Fagin, "When I want something nice to do/I go pick a pocket or two." 


\section{NOTES}

1. This paper derives from an essay "Translation and Language Games", from Hermeneutics and the Poetic Motion, volume 5 (in press) of Translation Perspectives, ed. Dennis J. Schmidt.

2. Van Den Abeele deserves our highest praise. The voice he gives Lyotard in The Differend is the voice Lyotard has when he uses English. This is proved conclusively to my satisfaction in Peregrenations (1988) which he wrote with David Carroll.

\section{BIBLIOGRAPHY}

DERRIDA, J. (1985): “Des Tours de Babel”, Difference in Translation, Ithaca, New York, Cornell, pp. 209-248, trans. Michelle Collins and Walter Verschueren for a conference by the same name at SUNY Binghamton, Fall.

DERRIDA, J. (1987): "Geschlecht II: Heidegger's Hand", trans. John P. Leavey Jr., in Deconstruction and Philosophy. The Texts of Jacques Derrida, John Sallis (ed.), University of Chicago.

DE WAARD, J. and E. A. NIDA (1986): From One Language to Another. Functional Equivalence in Bible Translating, Nashville, Thomas Nelson.

HOUSE, J. (1976): A Model for Translation Quality Assessment, Kronberg/ TS, Scriptor.

LYOTARD J.-F. with D. CARROLL (1988): Peregrenations, New York, Columbia University.

LYOTARD, J.-F. (1979): La Condition postmoderne, Paris, Éditions de Minuit, trans. Geoff Bennington and Brian Massumi, University of Minnesota, 1984.

LYOTARD, J.-F. (1983): Le Différend, Paris, Éditions de Minuit, trans. George Van Den Abbeele, in Diacritics, Fall 1984. Published in full as The Differend. Phrases in Dispute, University of Minnesota Press, 1988.

LYOTARD, J.-F. with J.-L. THÉBAUD (1979): Au juste, Paris, Christian Bourgois, pp. 103-104, trans. Wlad Godzich, Just Gaming, University of Minnesota, Theory \& History of Literature, 20, 1985.

SAINT-BEUVE, C.-A. (1933): Volupté, Maurice Allem (ed.), Paris, Garnier.

WILSS, W. (1985): "The Role of the Translator in the Translation Process", in Translation Perspectives, 2 , Binghamton, SUNY - Binghamton. 